\title{
INTERCULTURAL CAPITAL IN THE DEVELOPMENT OF THE POSTMODERN WORLD
}

\section{Mirzana Pašić Kodrić}

International University of Sarajevo

15, Hrasnička cesta, 71210 Ilidža, Sarajevo, Bosnia and Herzegovina

e-mail:mirzanapasic@yahoo.com

\begin{tabular}{|c|c|}
\hline open 0 access Cc & $\begin{array}{l}\text { Abstract. French sociologist Pierre Bourdieu (1984) defined } \\
\text { the term "cultural capital". This term denotes the stock of our }\end{array}$ \\
\hline $\begin{array}{l}\text { Article history: } \\
\text { Received: September, } 2019 \\
\text { 1st Revision: October, } 2019 \\
\text { Accepted: November, } 2019 \\
\end{array}$ & $\begin{array}{l}\text { cultural knowledge, and this phenomenon is also mapped into the } \\
\text { domains of interculturality. Thus, in postmodernity, intercultural } \\
\text { capital is increasingly talked about, which entails first acquiring } \\
\text { intercultural knowledge and then its practice at different levels, }\end{array}$ \\
\hline $\begin{array}{l}\text { JEL classification: } \\
\text { A13 }\end{array}$ & $\begin{array}{l}\text { with particular emphasis on the role of education in the process of } \\
\text { acquiring it. This type of education entails understanding, adopting } \\
\text { and nurturing intercultural phenomena such as intercultural }\end{array}$ \\
\hline $\begin{array}{l}\text { UDC: } \\
130.2,330.1\end{array}$ & $\begin{array}{l}\text { communication, competences, intercultural dialogue, sensibility, } \\
\text { etc. All of the above play a very important role in the global world } \\
\text { we live in, directly reflecting on all its aspects, including the }\end{array}$ \\
\hline $\begin{array}{l}\text { DOI: } \\
\text { https://doi.org/10.33108/sep } \\
\text { d2019.02.332 }\end{array}$ & $\begin{array}{l}\text { economic and business stability of the world. } \\
\text { Keywords: Intercultural Capital, Development, } \\
\text { Interculturality, Education }\end{array}$ \\
\hline
\end{tabular}

\section{Statement of the problem.}

In our postmodern age, interculturalism is increasingly aroused by the interest of the world academia, but also of societies and individuals in general, largely because of the overall complexity that the concept of interculturalism entails. But also because of the situation of general globalization processes and a number of other, extremely complex factors.

\section{Analysis of recent research and publications.}

In the fields of humanities, arts, political sciences, religious studies, communication sciences, studies of democracy, but also law, management and economy etc., various studies of culture and interculturalism are increasingly present. Every day we witness a huge, endless number of different publications in the fields of literature studies, linguistics, anthropology,

Kodrić M. Intercultural capital in the development of the postmodern world. Соціальноекономічні проблеми $і$ держава. 2019. Вип. 2(21). С.332-337. URL: http://sepd.tntu.edu.ua/images/stories/pdf/2019/19mpktpw.pdf 
history, psychology, sociology, gender studies, democracy, management, economics, etc., where these phenomena of culture and interculturalism increasingly take their place, thus becoming one of the favorite, almost burning topics of the world academic scene, but also of everyday life in general.

Cultural studies emerged as one of the more significant academic growth industries during the last quarter of the twentieth century, especially in last decade. It now has separate courses or departments in every continent but Antarctica. ${ }^{1}$

\section{Unsolved aspects of the problem.}

Although we are constantly witnessing an unprecedented number of publications in the field of interculturality, in practice the knowledge of this phenomenon still does not show its constant use. Both in the domains of education in general, at all educational levels and in all scientific fields, and in everyday life also. Interculturalism has been promoted as a positive value, but it is not sufficiently insisted on in all extremely positive aspects, as well as on ongoing intercultural practice.

\section{Task formulation.}

To make intercultural practice more present, both in education in general, but also in world business, politics, etc., and in everyday life, it is necessary to clarify and define the very concept of interculturalism and other basic, key concepts that this phenomenon refers to. Only in this way it's possible to understand the phenomenon of interculturalism in the context of developing intercultural capital, which plays one of the key roles in the development of a number of processes in the world, but also in global stability in general.

\section{Main material exposition.}

We regularly hear about the phenomena of culture and interculturalism in the media, but also read daily on commercials, billboards, art and photography exhibitions, websites, etc. We hear about it in everyday speech as one of the fundamental phenomena for understanding democracy, emancipation, identity and tolerance, history and political relations, current world conflicts, business, economics and management, but also the human rights of the individual.

Culture is a strange and capacious category. It is one of those concepts, perhaps the best example, that we simply cannot do without - it is used everywhere - but which is also very unsatisfactory and cries out for betterment. ${ }^{2}$

It is precisely in the overall complexity and the various spheres that this phenomenon encompasses that its broadest definition is one in which interculturality implies different relationships between individuals or groups situated between different cultures and opinions, relationships that are accompanied by the verbal and non-verbal interactions of those who enter into these processes, in all complexity that these relationships entail. ${ }^{3}$

As such, interculturalism inevitably manifests its dynamic character by the constant exchange of opinions, ideas and attitudes, including human communication through various forms of linguistic and non-linguistic communication. This, further, introduces one of the basic concepts in the sphere of interculturalism, and that is intercultural communication, which, in Karlfried Knapp's view, can be defined as an interaction between members of different groups, which differ from one another in respecting knowledge shared by their members. ${ }^{4}$

\footnotetext{
${ }^{1}$ Andrew Miller \& Jeff Browitt: Contemporary Cultural Theory, Routledge, London \& New York, 1994, p. 1.

${ }^{2}$ Barker, Chris: Cultural Studies, Sage Publications, London, 2000, p. xix

${ }^{3}$ Interculturalism - definition of the author of this paper

4 Knapp, Karlfried: Towards a definition of "Intercultural Communication", http://webdoc.gwdg.de/ edoc/ia/eese/strategy/knapp/4_st.html.
} 
When defining the term intercultural communication, it is of utmost importance to mention the meaning of the adjective intercultural, which implies not only the relationship "between" different cultures, but precisely the interaction - the relationship "between" and "among" different cultures. ${ }^{5}$

In all this, the question of defining the nature of identity of those who enter into intercultural communication is certainly important to be raised, since the character of the given communication depends on the characteristics of these identities, making it interculturally sensitive or not. This means that the complexity of intercultural communication is the biggest challenge precisely because of the complicated possibilities of this non-sensibility.

Namely, for a relationship to be called interculturally sensitive, the bearers of such a relationship must possess an intercultural identity, which implies: ${ }^{6}$

- Acceptance of existing and new cultural elements;

- Enriching the width and depth of sight;

- Greater self-understanding, self-acceptance and confidence;

- Increased openness and flexibility;

- Increased creativity to face new challenges.

Specifically, intercultural identities must be holders of intercultural competence, which, in Anne Schmid's view, represents knowledge about others, self-knowledge, ability to interpret and relate, ability to discover and/or influence, value the values, beliefs and behaviours of others, as and kinship. ${ }^{7}$

The ability of intercultural competence that bears intercultural identities achieves intercultural practice, which includes:

- Involvement of the entire community, not just the minority or majority;

- Taking into account the living environment shared by individuals of different backgrounds and analysing their place within the social structure;

- Involvement of professionals with specific abilities and skills that enable them to manage the difference in a non-traumatic and non-exclusive manner;

- Finding common elements within differences that enable the elaboration of ethnic and moral signifiers through an agreement that guarantees mutual respect and coexistence;

- Insisting on equal opportunities, rights and duties;

- Having a preventive dimension and develops a renewal of democracy in the event of a conflict.

All of the above:

- Confirms that cultural diversity exists in an individual context;

- Establishes a non-hierarchical frame of reference in interaction processes developed among subjects with different intercultural backgrounds;

- Cultural diversity is accepted and tolerated;

- Favours social adaptation to intercultural plurality;

- Interculturalism has been promoted as a positive value.

As such, the concepts of interculturalism are not only important in the social spheres of life, but also in literary studies, especially when it comes to travelogue, which is most often based precisely on intercultural challenges.

This knowledge of interculturalism enables a more realistic and objective view of all current processes of mobility in the world, its globalization and complex migration processes, the emergence of centers of power, but also facilitates the breaking of prejudices and established images of oneself, gender and others, etc. and other social changes involving the

\footnotetext{
${ }^{5} \mathrm{http} / / / \mathrm{www}$. yourdictionary.com/intercultural

${ }^{6} \mathrm{Kim}, \mathrm{Y}$. Y. Intercultural communication competence. Cross-cultural interpersonal communication, Sage, Newberry Park, CA, 1991, pp. 259-275.

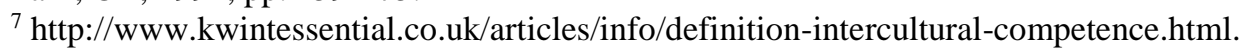


individual, society, and culture. All this clearly indicates the importance of education on basic intercultural concepts at all educational levels, as well as the importance of their use, on which almost all processes of world development directly depend. This means that the development of all segments of society, economy, general management, direct management of the world and its resources, etc. should to be considered objectively also in the context of knowledge about interculturalism and their concrete applications.

In this process, it could be a transformation, or we could view it as a process of collecting what the French sociologist Pierre Bourdieu (1984) calls "cultural capital". The term signifies a stock of our knowledge, whether in our heads or shown by a collection of cultural artefacts (like souvenirs). ${ }^{8}$

French sociologist Pierre Bourdieu (1984) defined the term "cultural capital". This term denotes the stock of our cultural knowledge, and this phenomenon is also mapped into the domains of interculturality. Thus, in postmodernity, intercultural capital is increasingly talked about. In this sense, at all educational levels, much more insistence should be placed on acquiring the so-called intercultural capital, first with individuals, then with the collective, which would imply the adoption of intercultural competences and knowledge and their clear application. Because of all this, all educational institutions have the great responsibility of first suggesting the importance of intercultural studies and their direct impact on the development of all world processes.

All this implies, therefore, the acquisition of the so-called intercultural capital, which includes:

- Constant desire for intercultural communication and awareness of its inevitability and importance, the impact on all world processes and the stability of the world;

- Acquisition of intercultural competences, including continuous learning of foreign languages, history and culture of other nations;

- Building intercultural sensibility with the understanding and respect that cultural frameworks differ, and within them systems of particular values;

- Fostering an intercultural identity that always promotes cultural difference as a value;

- Implementation of general intercultural practice that includes all of the above.

\section{Conclusions and recommendations for further researches}

Therefore, knowledge of interculturalism should be promoted more at all educational levels, in order to create, nurture and build up intercultural capital among students, as well as with the lecturers, managers, directors and representatives of various international companies and associations, etc. Learning about intercultural capital is a lifelong, interactive and mutual process on whose character also the economic and business stability of the world directly depends. Namely, the quality of intercultural education directly influences the development of all world processes and its general progress and stability.

\section{Author details (in Russian) МИРА \\ Мирзана Пасич Кодрич \\ Международный университет Сараево \\ ул. Грасничка честа, 15, г. Сараево, 71210 Илидза, Босния и Герцеговина \\ e-mail:mirzanapasic@yahoo.com} МЕЖКУЛЬТУРНЫЙ КАПИТАЛ В РАЗВИТИИ ПОСТМОДЕРНОГО

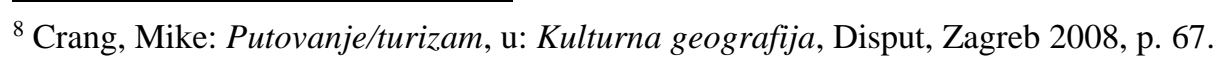


Аннотация. Французский социолог Пьер Бурдье (1984) дал определение термина "культурная столища", как запас наших культурных знаний, явление, которое отражено в сферах межкультурного. Таким образом, в постмодерновое время все чаще говорят о межкультурном капитале, который вызывает сначала получения межкультурных знаний, а затем - их практику на различных уровнях, с особым акцентом на роль образования в процессе ее приобретения. Этот тип образования указывает на необходимость понимания, принятия и воспитания межкультурных явлений, таких как межкультурная коммуникация, компетенции, межкультурный диалог, чувствительность и тому подобное. Все вышеперечисленное играет очень важную роль в глобальном мире, в котором мы живем, непосредственно влияя на все его аспекты, включая экономическую и деловую стабильность в мире.

Ключевые слова: межкультурный капитал, развитие, межкультурное, образование.

\title{
Author details (in Ukrainian) МІЖКУЛЬТУРНИЙ КАПІТАЛ В РОЗВИТКУ ПОСТМОДЕРНОГО СВІТУ Мірзана Пасіч Кодріч
}

\author{
Міжнародний університет Сараєво \\ вул. Граснічка честа, 15, м. Сараєво, 71210 Ілідза, Боснія і Герцеговина \\ e-mail:mirzanapasic@yahoo.com
}

Анотація. Французький соціолог П'єр Бурдьє (1984) дав означення терміну "культурна столищя", як запас наших культурних знань, явище, яке відображено у сферах міжкультурного. Таким чином, у постмодерний час все частіше говорять про міжкультурний капітал, що спричиняє спочатку отримання міжкультурних знань, а потім - їхню практику на різних рівнях, з особливим акцентом на роль освіти у процесі ї̈ набуття. Цей тип освіти вказує на необхідність розуміння, прийняття та виховання міжкультурних явищ, таких як міжкультурна комунікація, компетенції, міжкультурний діалог, чутливість тощо. Все вищезазначене відіграє дуже важливу роль у глобальному світі, в якому ми живемо, безпосередньо впливаючи на усі його аспекти, включаючи економічну та ділову стабільність у світі.

Ключові слова: міжкультурний капітал, розвиток, міжкультурність, освіта.

\section{Appendix A. Supplementary material}

Supplementary data associated with this article can be found, in the online version, at

http://sepd.tntu.edu.ua/images/stories/pdf/2019/19mpktpw.pdf

Funding

The authors received no direct funding for this research.

\section{Citation information}

Kodrić, M. (2019) Intercultural Capital in the Development of the Postmodern World. Sotsialno-ekonomichni problemy i derzhava [Socio-Economic Problems and the State] (electronic journal), Vol. 21, no. 2, pp.332-337. Available at: http://sepd.tntu.edu.ua/images/stories/pdf/2019/19mpktpw.pdf

\section{References}

1. Andrew Miller \& Jeff Browitt (1994) Contemporary Cultural Theory. Routledge, London \& New York, pp. 1.

2. Barker, Chris (2000) Cultural Studies, Sage Publications, London.

3. Crang, Mike (2008) Putovanje/turizam, u: Kulturna geografija. Disput, Zagreb.

4. Kim, Y.Y. (1991) Intercultural communication competence. Cross-cultural interpersonal communication, Sage Newberry Park, CA.

5. Knapp, Karlfried Towards a definition of "Intercultural Communication". Available at: http://webdoc.gwdg.de/ edoc/ia/eese/strategy/knapp/4_st.html.

6. Miller, Andrew \& Browitt, Jeff (1994) Contemporary Cultural Theory, Routledge, London \& New York. 
7. http://www.yourdictionary.com/intercultural.

8. http://www.kwintessential.co.uk/articles/info/definition-intercultural-competence.html.

Socio-Economic Problems and the State (ISSN: 2223-3822) is published by Academy of Social Management (ASM) and Ternopil Ivan Pul'uj National Technical University (TNTU), Ukraine, Europe.

Publishing with SEPS ensures:

- Immediate, universal access to your article on publication

- High visibility and discoverability via the SEPS website

- Rapid publication

- Guaranteed legacy preservation of your article

Discounts and waivers for authors in developing regions

Submit your manuscript to a SEPS journal at http://sepd.tntu.edu.ua 